\title{
Pengaruh Budaya Organisasi, Kedisiplinan, dan Kompetensi Terhadap Kinerja Pengawasan
}

\author{
Komang Sukma Saraswati ${ }^{1}$ \\ Ida Bagus Dharmadiaksa ${ }^{2}$ \\ ${ }^{1,2}$ Fakultas Ekonomi dan Bisnis Universitas Udayana (Unud), Bali, Indonesia \\ e-mail: komangsukma45@gmail.com
}

\begin{abstract}
ABSTRAK
Penelitian ini dilakukan di Inspektorat Daerah dan Badan Pengelolaan Keuangan dan Pendapatan Daerah Kabupaten Klungkung. Jumlah sampel yang diambil sebanyak 42 pegawai, dengan metode non-probability sampling, teknik proposive sampling. Pengumpulan data dilakukan melalui survei dan kuesioner. Teknik analisis yang digunakan adalah regresi linear berganda. Berdasarkan hasil analisis ditemukan bahwa budaya organisasi, kedisiplinan, dan kompetensi secara simultan berpengaruh signifikan terhadap kinerja pengawasan. Hal ini menunjukkan bahwa dijalankannya budaya organisasi yang baik, penerapan kedisiplinan dan penetapan standar kompetensi pada pegawai maka kinerja pengawasan akan membaik. Secara parsial budaya organisasi, kedisiplinan, dan kompetensi juga berpengaruh terhadap kinerja pengawasan. Hal ini menunjukkan bahwa dengan dijalankannya budaya organisasi yang baik, kedisiplinan dan kompetensi dapat meningkatkan kinerja pengawasan.
\end{abstract}

Kata kunci: Budaya organisasi, kedisiplinan, kompetensi

\begin{abstract}
This research was conducted at the Regional Inspectorate and the Regional Financial and Revenue Management Agency of Klungkung Regency. The number of samples taken as many as 42 employees, with non-probability sampling method, proposive sampling technique. Data collection is done through surveys and questionnaires. The analysis technique used is multiple linear regression. Based on the results of the analysis it was found that organizational culture, discipline, and competence simultaneously had a significant effect on supervisory performance. This shows that the implementation of a good organizational culture, the application of discipline and the establishment of competency standards for employees, the performance of supervision will improve. Partially organizational culture, discipline, and competence also influence supervisory performance. This shows that with the implementation of a good organizational culture, discipline and competence can improve supervisory performance.

Keywords: Organizational culture, discipline, competence
\end{abstract}

\section{PENDAHULUAN}

Kinerja pengawasan merupakan salah satu hal penting yang harus diperhatikan untuk mengembangkan suatu organisasi, karena kinerja pengawasan dapat mengontrol jalannya suatu organisasi sesuai dengan yang telah direncanakan(Purwati, 2017). Dalam pemerintahan, untuk melaksanakan 
Komang Sukma Saraswati dan Ida Bagus Dharmadiaksha. Pengaruh ...

pembangunan membutuhkan pembiayaan yang berasal dari Anggaran Pendapatan dan Belanja Negara atau Daerah. Searah dengan adanya otonomi daerah maka masing- masing daerah harus mengelola keuangan daerahnya dengan baik (Limbunan \& Tarigan, 2016).

Perlimpahan tanggungjawab akan diikuti oleh pengaturan, pembagian, pemanfaatan, dan sumber daya nasional yang berkeadilan, serta perimbangan keuangan pusat dan daerah(Iriani, 2010). Berdasarkan pernyataan tersebut maka pengelolaan keuangan yang dilakukan dengan efisien dan efektif harusberjalan secara optimal, karena hal ini berkaitan dengan target dan realisasi penerimaan daerah namun dalam realisasinya masih tidak sesuai dengan target karena hal ini berkaitan dengan dana pembangunan. Apabila pengelolaan keuangan sudah efisien dan efektif ini berarti bahwa adanya suatu jaminan ketersediaan dana pembangunan, dan apabila pengelolaan keuangan belum efisien dan efektif maka perlu dorongan agar pengelolaan keuangan membaik sehingga akan menjamin ketersediaan dana untuk pembangunan itu sendiri dan akan menghasilkan kinerja keuangan yang baik atau berkualitas (Arifin, 2014).

Berdasarkan pernyataan diatas, untuk mewujudkan laporan keuangan yang berkualitas diperlukan adanya pengawasan. Pengawasan adalah proses dalam menetapkan ukuran kinerja dan pengambilan tindakan yang dapat mendukung pencapaian hasil yang diharapkan sesuai dengan kinerja yang telah ditetapkan tersebut. Pengawasan adalah proses untuk memastikan bahwa segala aktifitas yang terlaksana sesuai dengan apa yang telah direncanakan (Lillati, 2014). 
Upaya pemerintah daerah untuk meningkatkan kualitas pelayanan publik terhadap masyarakat terus dilakukan. Adanya Undang-undang Nomor 17 tahun 2003 tentang keuangan negara, yang diperkuat dengan Peraturan Pemerintah Nomor 8 tahun 2006 tentang pelaporan keuangan dan kinerja instansi pemerintah menyatakan bahwa dalam pelaporan keuangan harus disertakan informasi mengenai kinerja instansi pemerintah, yakni prestasi yang berhasil dicapai oleh pengguna anggaran sehubungan dengan anggaran yang telah digunakan(Rahayu, Kennedy, \& Anisma, 2014). Pemerintah Daerah selaku pengelola dana publik harus sanggup menyediakan informasi keuangan secara akurat, relevan, tepat waktu, dan dapat dipercaya(Widari \& Indartono, 2015).

Kinerja keuangan salah satunya dapat dilihat dari opini Badan Pemeriksa Keuangan (BPK)(Yosefrinaldi, 2017). Adapun strata penilaian laporan keuangan dari hasil pemeriksaan yang dilakukan BPK, dimulai dari strata tertinggi adalah Wajar Tanpa Pengecualian (WTP) kemudian selanjutnya adalah Wajar Dengan Pengecualian (WDP), Tidak Wajar (TW), dan Tidak Menyatakan Pendapat (TMP). Selain opini dari BPK, kinerja keuangan dapat dilihat juga apabila telah disusun sesuai dengan Standar Akuntansi Pemerintahan (SAP), disusun melalui sistem akuntansi pemerintah daerah, informasi keuangan tidak terdapat penyimpangan dari peraturan perundang-undangan, dan disajikan secara tepat waktu sesuai dengan peraturan perundang-undangan(Herawati, Suputra, \& Budiasih, 2016).

Berdasarkan laporan hasil pemeriksaan BPK sepanjang semester II- 2017 untuk tahun pelaporan 2016, BPK mencatat masih banyak laporan keuangan 
pemerintah daerah (LKPD) yang belum memperoleh opini WTP. Dalam LKPD 2016, tercatat hanya 70 persen atau 378 LKPD yang memperoleh opini WTP. LKPD lainnya tercatat memperoleh opini lain yaitu WDP tercatat sebanyak 141 LKPD, dan opini TMP sebanyak 23 LKPD. BPK juga mengungkapkan 10.198 temuan yang memuat 15.568 permasalahan. 51 persen permasalahan adalah ketidakpatuhan terhadap ketentuan peraturan perundang-undangan. Ketidakpatuhan tersebut berkaitan dengan penyerahan laporan keuangan pemerintah daerah yang tidak tepat waktu (bpk.go.id).

Tabel 1.

Laporan Hasil Pemeriksaan BPK Tahun 2013-2017

\begin{tabular}{ccc}
\hline Entitas Pemerintah Daerah & Tahun & Opini BPK \\
\hline \multirow{3}{*}{ Kabupaten Klungkung } & 2013 & WDP \\
& 2014 & WDP \\
& 2015 & WTP \\
& 2016 & WTP \\
\hline
\end{tabular}

Sumber: Ikhtisar Hasil Pemeriksaan Semester, 2017

Berdasarkan Tabel 1 laporan hasil pemeriksaan BPK untuk tahun pelaporan 2015, 2016 dan 2017 Kabupaten Klungkung berhasil memperoleh opini WTP namun apabila dilihat dari opini BPK tahun 2013 dan 2014 Klungkung masih mendapat opini WDP. Kualitas LKPD Kabupaten Klungkung terlihat meningkat, maka penelitian ini dilakukan di Pemerintah Daerah Kabupaten Klungkung.

Untuk mencapai keberhasilan sebuah organisasi diperlukan perilaku organisasi yang baik karena perilaku organisasi sesungguhnya terbentuk dari perilaku-perilaku individu sebagai penggerak organisasi tersebut(Fleenor, 2014). Kinerja yang baik dalam organisasi akan tercapai apabila diimbangi dengan kinerja seorang pegawai atau sember daya manusia yang berkualitas. Sumber daya 
merupakan sumber energi, tenaga, kekuatan (power) yang diperlukan untuk menciptakan daya, gerakan, aktivitas, kegiatan, dan tindakan(Cameron \& Quinn, 2013). Dalam mencapai kinerja yang baik dalam organisasi tergantung pada kinerja pegawai yang bergerak menjalankan tujuan organisasi tersebut karena pegawai bukan hanya menjadi objek dalam pencapaian keberhasilan sebuah organisasi namun juga sebagai pelaku keberhasilan organisasi tersebut(Ali, 2017).

Berdasarkan penelitian yang dilakukanSatria (2017)prestasi kerja dapat dicapai oleh beberapa faktor yang pertama yaitu budaya organisasi. Budaya organisasi adalah suatu pola dari asumsi-asumsi dasar yang ditemukan, diciptakan atau dikembangkan oleh suatu kelompok tertentu dengan maksud agar organisasi bisa mengatasi, menanggulangi permasalahan yang timbul akibat adaptasi eksternal dan integritas internal yang sudah berjalan dengan cukup baik sehingga lebih mudah dalam mencapai tujuan organisasi. Budaya organisasi sering juga disebut dengan budaya kerja karena tidak bisa dipisahkan dengan kinerja sumber daya manusia yang ada pada organisasi tersebut. Sebuah organisasi yang memiliki budaya kerja yang baik, dapat dilihat dan diamati oleh peninjauan dari luar maupun dalam organisasi tersebut. Pengamat tersebut akan merasakan suasana kerja yang khas yang membedakan organisasi tersebut dengan organisasi lainnya.Agar kinerja pengawasan dapat dicapai dengan baik, maka salah satu yang harus dilakukan organisasi adalah menanamkan budaya organisasi yang baik kepada pegawainya (Arifin, 2014).

Disamping budaya organisasi, menurut Satria (2017)faktor lain yang mempengaruhi prestasi kerja yaitu kedisiplinan. Secara umum pengertian disiplin 
Komang Sukma Saraswati dan Ida Bagus Dharmadiaksha. Pengaruh ...

adalah kesadaran dan kesediaan seseorang mentaati semua peraturan organisasi dan norma-norma sosial yang berlaku. Kesadaran adalah suatu sikap secara sukarela mentaati semua peraturan organisasi dan sadar akan tanggungjawabnya. Kesediaan adalah suatu sikap tingkah laku atau perbuatan organisasi baik tertulis maupun tidak. Tidak dapat dipungkiri bahwa kedisiplinan sering menimbulkan permasalahan tersendiri bagi organisasi (Anthony, 2017). Menurut Iriani (2010)kedisiplinan pegawai mutlak diperlukan agar seluruh aktivitas yang sedang dan akan dilaksanakan berjalan sesuai dengan mekanisme yang telah ditentukan. Kedisiplinan dalam hal ini yaitu dalam laporan yang disampaikan oleh pegawai haruslah relevan, andal, lengkap dan selesai tepat waktu sehingga informasi yang dihasilkan tidak kadaluarsa. Informasi akuntansi yang disajikan harus tepat waktu agar pengambilan keputusan organisasi juga bisa dilaksanakan pada waktu yang sudah direncanakan. Apabila informasi akuntansi muncul terlambat, tentu akan berimbas pada pengambil keputusan(Ariesta, 2013). Hasilnya akan berpengaruh pada pengambilan keputusan yang ikut terlambat atau informasi akuntansi itu tidak terpakai.Tanpa adanya kedisiplinan yang tinggi, konsistensi akan sulit untuk dicapai. Konsisten membutukan kedisiplinan agar dapat mentaati prosedur dan aturan organisasi itu sendiri, tidak menyepelekan data atau fakta sekecil apa pun, taat pada aturan pemerintah, taat pada standar kode etik, serta dapat taat pada prinsip yang berterima umum dan praktek yang lazim, sehingga kinerja pengawasan yang baik dapat tercapai.

Faktor yang mempengaruhi prestasi kerja menurut Satria (2017)yang terakhir yaitu kompetensi. MenurutNwinyokpugi(2018) kompetensi merupakan 
karakteristik individu yang mendasari kinerja atau perilaku ditempat kerja. C \& Victoria (2011)menyatakan bahwa kompetensi merupakan dimensi perilaku organisasi yang berada dibelakang kinerja kompeten. Sering dinamakan kompetensi perilaku karena dimaksudkan untuk menjelaskan bagaimana orang berperilaku ketika mereka menjalankan perannya dengan baik. Berikut beberapa pengertian kompetensi menurut para ahli. Menurut Hertati (2015)kompetensi adalah krakteristik perilaku yang menggambarkan motif, sifat, konsep diri, nilainilai, pengetahuan atau keterampilan yang dimiliki orang yang berkinerja superior di tempat kerja. Sedangkan kompetensi menurut Lee, Chong, \& Ramayah (2018)adalah suatu kemampuan untuk melaksanakan atau melakukan suatu pekerjaan atau tugas yang dilandasi atas keterampilan dan pengetahuan serta didukung oleh sikap kerja yang dituntut oleh pekerjaan tersebut. Berdasarkan pendapat diatas maka dapat disimpulkan bahwa yang dimaksud dengan kompetensi adalah kemampuan untuk melakukan suatu pekerjaan secara efektif dan efisien dengan didasari sikap profesional. Jika dikaitkan dengan Organisasi Perangkat Daerah (OPD) maka dalam pengelolaan keuangan agar menghasilkan kineja keuangan daerah yang baik, OPD harus memiliki sumber daya manusia yang berkompeten yang didukung dengan latar belakang akuntansi. Sehingga untuk menerapkan sistem akuntasi, sumber daya manusia yang berkompeten tersebut akan mampu memahami logika akuntansi dengan baik. Kegagalan sumber daya manusia pada Pemerintah Daerah dalam memahami dan menerapkan logika akuntansi akan berdampak pada kekeliruan laporan keuangan yang dibuat dan ketidaksesuaian laporan dengan standar yang ditetapkan pemerintah. 
Davidson (2013)menyatakan bahwa budaya yang kuat dapat menghasilkan efek yang sangat mempengaruhi individu dan kinerja, bahkan dalam suatu lingkungan bersaing pengaruh tersebut dapat lebih besar daripada faktor-faktor lain seperti struktur organisasi, alat analisis keuangan, kepemimpinan dan lainlain. Berdasarkan pandanganYesil \& Kaya (2013)budaya organisasi yang mudah menyesuaikan dengan perubahan jaman adalah yang dapat meningkatkan kinerja. Menurut Hoorn (2017)organisasi yang baik, tumbuh dan berkembang akan memperhatikan pengelolaan sumber daya manusia guna menjalankan fungsinya dengan optimal, khususnya menghadapi dinamika perubahan lingkungan yang terjadi. James \& Nyongesa (2012)menemukan bahwa nilai budaya atau culture dapat meningkatkan sebuah komitmen. Jika komitmen pegwai telah diperoleh, akan didapatkan pegawai yang setia dan mampu bekerja sebaik mungkin untuk kepentingan perusahaan atau organisasi. MenurutEarnhardt \& Bateman (2015) salah satu karakteristik budaya organisasi adalah memiliki nilai-nilai yang berkaitan dengan aturan dan keuntungan yang ditekankan sehingga dapat meningkatkan perfoma yang dimiliki oleh organisasi. Dengan adanya salah satu karakteristik ini, kita dapat mengetahui bahwa budaya organisasi berpengaruh terhadap kinerja pengawasan

Berdasarkan hasil penelitian Golafzani \& Chirani (2016)budaya organisasi berpengaruh negatif terhadap kinerja keuangan.Davidson (2013) juga menunjukkan budaya organisasi dapat mempengaruhi kinerja keuangan perusahaan. Penelitian lainnya yang dilakukan oleh Limbunan \& Tarigan (2016) 
juga memberikan hasil bahwa budaya organisasi memberi pengaruh positif dan signifikan terhadap kinerja keuangan. Ini berarti semakin baik kualitas budaya organisasi di dalam suatu organisasi maka tujuan organisasi yang mana dalam penelitian ini adalah kinerja keuangan yang baik akan mudah tercapai. Oleh karena itu, dalam penelitian ini terbentuklah hipotesis sebagai berikut:

$\mathrm{H}_{1}$ : Budaya organisasi berpengaruh positif terhadap kinerja pengawasan di Pemerintah Daerah Kabupaten Klungkung.

Menurut Malayu (2015: 149) disiplin adalah fungsi operatif dari manajemen sumber daya manusia yang terpenting karena semakin baik disiplin pegawai, semakin tinggi kinerja yang dapat dicapai seorang pegawai. Menurut Moenir (2004: 25) disiplin pada dasarnya selalu diharapkan menjadi ciri setiap SDM dalam organisasi, karena dengan kedisiplinan organisasi akan berjalan dengan baik dan bisa mencapai tujuannya dengan baik pula. Setiap pegawai harus memiliki disiplin kerja didalam organisasi atau perusahaannya, seperti mematuhi peraturan tertulis maupun tidak tertulis yang telah di tetapkan oleh negara maupun organisasi karena hal tersebut dapat menciptakan lingkungan kerja yang kondusif dan harmonis sehingga akan memberikan dampak yang positif terhadap kinerja karyawannya. Kedisiplinan pegawai mutlak diperlukan agar seluruh aktivitas yang sedang dan akan dilaksanakan berjalan sesuai dengan mekanisme yang telah ditentukan(Iriani, 2010). Kedisiplinan dalam hal ini yaitu dalam laporan yang disampaikan oleh pegawai haruslah relevan dan selesai tepat waktu sehingga tidak kadaluarsa. Menurut Halim (2013:67) informasi akuntansi yang disajikan harus tepat waktu agar pengambilan keputusan perusahaan juga bisa dilaksanakan pada waktu yang sudah direncanakan. Jika informasi akuntansi muncul terlambat, 
tentu akan berimbas pada pengambil keputusan. Hasilnya akan berpengaruh pada pengambilan keputusan yang ikut terlambat atau informasi akuntansi itu tidak terpakai.Tanpa adanya kedisiplinan yang tinggi, konsistensi akan sulit untuk dicapai. Konsisten membutukan kedisiplinan agar dapat mentaati prosedur dan aturan organisasi itu sendiri, tidak menyepelekan data atau fakta sekecil apa pun, taat pada aturan pemerintah, taat pada standar kode etik, serta dapat taat pada prinsip yang berterima umum dan praktek yang lazim, sehingga kinerja pengawasan yang baik dapat tercapai (Nwinyokpugi, 2018).

Berdasarkan penelitian yang dilakukan oleh Herawati et al., (2016)disiplin kerja memiliki pengaruh yang signifikan positif terhadap kinerja pegawai. Selain itu, penelitian yang dilakukan oleh Widari \& Indartono (2015)disiplin berpengaruh positif dan signifikan terhadap kinerja pegawai BKD DIY. Ini berarti semakin tinggi kedisiplinan seorang pegawai di dalam suatu organisasi maka tujuan organisasi yang mana dalam penelitian ini adalah kinerja pengawasan yang baik akan mudah tercapai.Oleh karena itu, dalam penelitian ini terbentuklah hipotesis sebagai berikut:

$\mathrm{H}_{2}$ : Kedisiplinan berpengaruh positif terhadap kinerja pengawasandi Pemerintah Daerah Kabupaten Klungkung.

Menurut Hertati (2015)sumber daya manusia adalah seseorang atau individu yang mempunyai tanggungjawab untuk melaksanakan tugas. Lyle Spencer dan Signe Spencer dalam Moeheriono (2012:5) menyatakan bahwa kompetensi adalah karakteristik yang mendasari seseorang berkaitan dengan efektivitas kinerja individu dalam pekerjaannya atau karakteristik individu yang memiliki hubungan kausal atau sebagai sebab akibat dengan kriteria yang 
dijadikan acuan, efektif atau berkinerja prima superior ditempat kerja pada situasi tertentu. Kompetensi merupakan variabel utama yang harus dimiliki oleh seorang pegawai dalam melaksanakan pekerjaannya sehingga dengan adanya kompetensi yang telah dimiliki dapat membantu para pegawai di dalam menyelesaikan pekerjaan sesuai dengan target yang telah ditentukan organisasi. Menurut Keputusan Kepala Badan Kepegawaian Negara No 46 A Tahun 2003 yang menyatakan bahwa kompetensi adalah kemampuan dan karakteristik yang dimiliki oleh seorang pegawai negeri sipil berupa pengetahuan, keterampilan, dan sikap perilaku yang diperlukan dalam pelaksanaan tugas jabatannya, sehingga pegawai negeri tersebut dapat melaksanakan tugasnya secara profesional, efektif dan efisien. Penentuan tingkat kompetensi dibutuhkan agar dapat mengetahui tingkat kinerja yang diharapkan untuk kategori baik dan ratarata. Penentuan ambang batas kompetensi yang dibutuhkan tentunya akan dapat dijadikan dasar bagi proses seleksi, perencanaan, evaluasi kinerja dan pengembangan sumber daya manusia. Kompetensi sumber daya manusia yang memadai dari segi kuantitas dan kualitas akan meningkatkan kandungan nilai informasi dalam pelaporan keuangan pemerintah daerah.

Menurut Herawati et al., (2016) pada dasarnya transparansi dan akuntabilitas dalam pengelolaan keuangan daerah sebagai sebuah implementasi kebijakan publik dalam praktik yang memerlukan kompetensi sumber daya manusia yang memadai dari segi jumlah dan keahlian (kompetensi, pengalaman, serta informasi yang memadai), disamping pengembangan kompetensi organisasi. Berdasarkan penelitian sebelumnya yang berkaitan dengan uraian di 
Komang Sukma Saraswati dan Ida Bagus Dharmadiaksha. Pengaruh ...

atas yang telah dilakukan oleh Rostarina (2015)yang menyatakan bahwa kompetensi sumber daya manusia berpengaruh positif terhadap kualitas laporan keuangan Daerah. Iriani (2010) menemukan hasil bahwa terdapat pengaruh kompetensi, disiplin kerja, pendidikan dan latihan, perjenjangan karir secara simultan bersama-sama terhadap kinerja Pegawai. Serdasarkan penelitian yang dilakukan oleh Rahayu et al., (2014)menemukan hasil bahwa kompetensi sumber daya manusia berpengaruh signifikan positif terhadap kualitas laporan keuangan pemerintah daerah. Menurut penelitian (Ariesta, 2013)mengungkapkan bahwa kompetensi sumber daya manusia berpengaruh signifikan terhadap keterandalan dan ketepatwaktuan. Menurut hasil penelitian Satria (2017)menunjukkan bahwa kompetensi sumber daya manusia berpengaruh signifikan positif terhadap nilai pelaporan keuangan daerah. Ini berarti semakin tinggi kompetensi pegawai dalam pengelolaan laporan keuangan daerah maka akan semakin tinggi kualitas kinerja pengawasan yang dihasilkan. Oleh karena itu, dalam penelitian ini terbentuklah hipotesis sebagai berikut:

$\mathrm{H}_{3}$ : Kompetensi berpengaruh positif terhadap kinerja pengwasandi Pemerintah Daerah Kabupaten Klungkung.

\section{METODE PENELITIAN}

Lokasi penelitian ini dilakukan di Inspektorat Daerah dan Badan Pengelolaan Keuangan dan Pendapatan Daerah (BPKPD) di Pemerintah Daerah Kabupaten Klungkung. Alasan penulis memilih Inspektorat Daerah sebagai tempat penelitian karena OPD ini merupakan organisasi yang memiliki tim audit untuk melakukan pengawasan terhadap LKPD yang disusun oleh seluruh OPD di Kabupaten 
Klungkung. Alasan penulis memilih BPKPD sebagai tempat penelitian karena salah satu tugasnya yaitu merangkap seluruh LKPD yang disusun oleh seluruh OPD di Kabupaten Klungkung.

Populasi yang digunakan dalam penelitian ini adalah pegawai di Inspektorat Daerah sebanyak 36 pegawai dan BPKPD Kabupaten Klungkung sebanyak 82 pegawai, jadi jumlah populasi keseluruhan sebanyak 118 pegawai. Alasan penulis memilih pegawai Inspektorat Daerah sebagai populasi penelitian karena OPD ini merupakan organisasi yang memiliki tim audit untuk melakukan pengawasan terhadap LKPD yang disusun oleh seluruh OPD di Kabupaten Klungkung. Alasan penulis memilih pegawai BPKPD sebagai populasi penelitian karena salah satu tugasnya yaitu merangkap seluruh LKPD yang disusun oleh seluruh OPD di Kabupaten Klungkung. Penelitian ini menggunakan metodenonprobability samplingyaitu setiap anggota populasi memiliki peluang nol, artinya pengambilan sampel didasarkan kriteria tertentu seperti judgment, status, kuantitas, kesukarelaan dan sebagainya.Teknik penentuan sampel dalam penelitian ini adalah teknik purposive sampling yaitu teknik penentuan sampel dengan pertimbangan tertentu.

Teknik analisis data yang digunakan dalam penelitian ini adalah analisis regresi linear berganda. Analisis data didasarkan pada kuesioner yang dinilai berdasarkan skala likert. Tahapan analisis ini adalah statistik deskriptif, uji asumsi klasik (uji normalitas, uji multikolinieritas dan uji heteroskedastisitas), analisis regresi linear berganda, koefisien determinasi, uji statistik F (uji kelayakan model) dan uji statistik t (uji hipotesis). 
Analisis regresi berganda (multiple linear regression) digunakan untuk menguji hipotesis yang ada yaitu untuk melihat pengaruh variabel gaya kepemimpinan situasional, motivasi dan pelatihan terhadap kinerja karyawan, maka ditentukan bentuk model persamaan analisis regresi linier berganda sebagai berikut:

$\mathrm{Y}=\alpha+\beta_{1 .} \mathrm{X} 1+\beta_{2 .} \mathrm{X} 2+\beta_{3} \mathrm{X} 3+\mathrm{e}$

Keterangan :

$\mathrm{Y}=$ Kinerja Pengawasan

A $\quad=$ Konstanta

$\beta_{1 \ldots} \beta_{4}=$ Koefisien Regresi

$\mathrm{X}_{1} \quad=$ Budaya Organisasi

$\mathrm{X}_{2} \quad=$ Kedisiplinan

$\mathrm{X}_{3} \quad=$ Kompetensi

$\mathrm{e} \quad=$ Variabel Penggangu

\section{HASIL DAN PEMBAHASAN}

Berdasarkan hasil olahan SPSS 22 yang meliputi variabel budaya organisasi, kedisipinan, kompetensi dan kinerja pengawasan, didapat hasil analisis data untuk statistik deskriptif yang dapat dilihat pada Tabel 2. 
Tabel 2.

Hasil Statistik Deskriptif

\begin{tabular}{cccccc}
\hline Variabel & $\mathrm{N}$ & Minimum & Maksimum & Mean & Std. Deviasi \\
\hline $\mathrm{Y}$ & 78 & 8,49 & 26,66 & 20,4633 & 6,18469 \\
$\mathrm{X}_{1}$ & 78 & 7,44 & 22,91 & 17,1390 & 5,10629 \\
$\mathrm{X}_{2}$ & 78 & 5,26 & 14,80 & 11,4879 & 3,27929 \\
$\mathrm{X}_{3}$ & 78 & 8,35 & 26,22 & 20,7288 & 5,92750 \\
Valid N (Listwis) & 78 & & & &
\end{tabular}

Sumber: Data diolah, 2018

Berdasarkan statistik deskriptif yang ditunjukkan Tabel 2 digunakan nilai terendah dari kinerja pengawasan sebesar 8,49 dan nilai tertinggi sebesar 26,66. Nilai rata-rata dari kinerja pengawasan adalah 20,4633. Ini menunjukkan bahwa nilai rata-rata variabel kinerja pengawasan mendekati nilai maksimum daripada nilai minimumnya. Hal ini menandakan bahwa rata-rata kinerja pengawasan di Pemerintah Daerah Kabupaten Klungkung tinggi. Nilai standar deviasi sebesar 6,18469 yang tidak melebihi dua kali rata-ratanya menunjukkan bahwa rentang antara nilai terendah dengan nilai tertinggi tidak terlalu jauh, artinya responden cenderung setuju bahwa kinerja pengawasan di pemerintah daerah Kabupaten Klungkung dalam kondisi baik.

Berdasarkan statistik deskriptif yang ditunjukkan Tabel 2 digunakan nilai terendah dari variabel budaya organisasi sebesar 7,44 dan nilai tertinggi sebesar 22,91. Nilai rata-rata dari variabel budaya organisasi adalah 17,1390. Ini menunjukkan bahwa nilai rata-rata variabel budaya organisasi mendekati nilai maksimum daripada nilai minimumnya. Hal ini berarti rata-rata responden berpendapat bahwa indikator budaya organisasi cenderung menyebabkan kinerja pengawasan membaik. Nilai standar deviasi sebesar 5,10629 yang tidak melebihi dua kali rata-ratanya menunjukkan bahwa rentang antara nilai terendah dengan nilai tertinggi tidak terlalu jauh, artinya responden cenderung setuju bahwa 
Komang Sukma Saraswati dan Ida Bagus Dharmadiaksha. Pengaruh ...

budaya organisasi yang sudah dijalankan pemerintah daerah Kabupaten Klungkung selama ini sudah baik.

Berdasarkan statistik deskriptif yang ditunjukkan Tabel 2 digunakan nilai terendah dari kedisiplinan sebesar 5,26 dan nilai tertinggi sebesar 14,80. Nilai rata-rata dari kedisiplinan adalah 11,4879 . Ini menunjukkan bahwa nilai rata-rata variabel kedisiplinan mendekati nilai maksimum daripada nilai minimumnya. Hal ini berarti rata-rata responden berpendapat bahwa indikator kedisiplinan cenderung menyebabkan kinerja pengawasan membaik. Nilai standar deviasi sebesar 3,27929 yang tidak melebihi dua kali rata-ratanya menunjukkan bahwa rentang antara nilai terendah dengan nilai tertinggi tidak terlalu jauh, artinya responden cenderung setuju kedisiplinan yang telah diterapkan pemerintah daerah Kabupaten Klungkung selama ini sudah baik.

Berdasarkan statistik deskriptif yang ditunjukkan Tabel 2 digunakan nilai terendah dari kompetensi sebesar 8,35 dan nilai tertinggi sebesar 26,22. Nilai rata-rata dari kompetensi adalah 20,7288. Ini menunjukkan bahwa nilai rata-rata variabel kompetensi mendekati nilai maksimum daripada nilai minimumnya. Hal ini berarti rata-rata responden berpendapat bahwa indikator kompetensi cenderung menyebabkan kinerja pengawasan membaik. Nilai standar deviasi sebesar 5,92750 yang tidak melebihi dua kali rata-ratanya menunjukkan bahwa rentang antara nilai terendah dengan nilai tertinggi tidak terlalu jauh, artinya responden cenderung setuju standar kompetensi yang telah ditetapkan pemerintah daerah Kabupaten Klungkung selama ini sudah tepat.

Hasil uji reliabilitas pada penelitian ini disajikan pada Tabel 3 berikut. 
Tabel 3.

Hasil Uji Reliabilitas

\begin{tabular}{lcc}
\hline \multicolumn{1}{c}{ Variabel } & Koefisien Alpha Cronbach & Keterangan \\
\hline Budaya Organisasi & 0,924 & Reliabel \\
Kedisiplinan & 0,839 & Reliabel \\
Kompetensi & 0,935 & Reliabel \\
Kinerja Pengawasan & 0,953 & Reliabel \\
\hline Sumber:Data diolah, 2018 & &
\end{tabular}

Berdasarkan hasil uji reliabilitas yang disajikan dalam Tabel 3 dapat disimpulkan bahwa variabel-variabel yang digunakan dalam penelitian ini adalah reliabel karena keseluruhan variabel memiliki Cronbach's Alpa yang lebih dari 0,70sehingga layak digunakan menjadi alat ukur instrumen kuesioner dalam penelitian ini.

Pengujian ini dilakukan dengan menghitung nilai Pearson Correlation. Jumlah item dalam kuesioner ini adalah sebanyak 24 item. Tabel 4 menyajikan hasil uji validitas instrument penelitian sebagai berikut.

Tabel 4.

Hasil Uji Validitas

\begin{tabular}{|c|c|c|c|c|}
\hline No & Variabel & $\begin{array}{c}\text { Item } \\
\text { Pernyataan }\end{array}$ & $\begin{array}{c}\text { Pearson } \\
\text { correlation }\end{array}$ & Keterangan \\
\hline \multirow[t]{6}{*}{1} & Budaya Organisasi & $\mathrm{X} 1.1$ & 0,906 & Valid \\
\hline & & $\mathrm{X} 1.2$ & 0,870 & Valid \\
\hline & & $\mathrm{X} 1.3$ & 0,853 & Valid \\
\hline & & $\mathrm{X} 1.4$ & 0,862 & Valid \\
\hline & & $\mathrm{X} 1.5$ & 0,744 & Valid \\
\hline & & $\mathrm{X} 1.6$ & 0,867 & Valid \\
\hline \multirow[t]{4}{*}{2} & Kedisiplinan & $\mathrm{X} 2.1$ & 0,719 & Valid \\
\hline & & $\mathrm{X} 2.2$ & 0,870 & Valid \\
\hline & & $\mathrm{X} 2.3$ & 0,863 & Valid \\
\hline & & $\mathrm{X} 2.4$ & 0,827 & Valid \\
\hline \multirow[t]{7}{*}{3} & Kompetensi & X3.1 & 0,811 & Valid \\
\hline & & X3.2 & 0,868 & Valid \\
\hline & & $\mathrm{X} 3.3$ & 0,860 & Valid \\
\hline & & X3.4 & 0,829 & Valid \\
\hline & & X3.5 & 0,932 & Valid \\
\hline & & X3.6 & 0,853 & Valid \\
\hline & & X3.7 & 0,774 & Valid \\
\hline \multirow[t]{5}{*}{4} & Kinerja Pengawasan & Y.1 & 0,919 & Valid \\
\hline & & Y.2 & 0,911 & Valid \\
\hline & & Y.3 & 0,845 & Valid \\
\hline & & Y.4 & 0,888 & Valid \\
\hline & & Y.5 & 0,873 & Valid \\
\hline
\end{tabular}




\begin{tabular}{cccc} 
& Y.6 & 0,888 & Valid \\
& Y.7 & 0,859 & Valid \\
\hline
\end{tabular}

Sumber: Data diolah, 2018

Berdasarkan Tabel 4 dapat dilihat bahwa instrumen penelitian yang terdiri dari item-item pertanyaan budaya organisasi $\left(\mathrm{X}_{1}\right)$, kedisiplinan $\left(\mathrm{X}_{2}\right)$, kompetensi $\left(\mathrm{X}_{3}\right)$, kinerja pengawasan $(\mathrm{Y})$ adalah valid. Hal ini dikarenakan korelasi antara skor masing - masing pertanyaan dengan skor total besarnya diatas 0,30 .

Hasil uji multikolinearitas disajikan pada Tabel 5 berikut.

Tabel 5.

\section{Hasil Uji Normalitas}

\begin{tabular}{llr}
\hline & & Unstandardized Residual \\
\hline $\mathrm{N}$ & & 42 \\
Normal Parameters & Mean & 0,0000000 \\
& Std. Deviation & 0,22937611 \\
Most Extreme Differences & Absolute & 0,129 \\
& Positive & 0,086 \\
Test Statistic & Negative & $-0,129$ \\
Asymp. Sig. (2-tailed) & & 0,129 \\
\hline Sumber: Data diolah, 2018 & & $0,075^{\mathrm{d}}$ \\
\hline
\end{tabular}

Berdasarkan Tabel 5 menunjukkan bahwa nilai signifikansi dari hasil uji normalitas pada persamaan tersebut sebesar 0,075. Hal tersebut berarti bahwa data berdistribusi normal karena nilai Asymp. Siglebih dari 0,05.

Hasil uji multikolinearitas disajikan pada Tabel 6 berikut.

Tabel 6.

Hasil Uji Multikolinearitas

\begin{tabular}{crrrrr}
\hline Model & \multicolumn{2}{c}{ Unstandardized } & \multicolumn{2}{c}{$\begin{array}{c}\text { Standardized } \\
\text { Coefficients }\end{array}$} & \multicolumn{2}{c}{ Collinearity Statistics } \\
& $\begin{array}{c}\text { Coefficients } \\
\text { B }\end{array}$ & $\begin{array}{c}\text { Std. } \\
\text { Error }\end{array}$ & & Tolerance & VIF \\
\hline (Constant) & $-1,749$ & 2,600 & & & \\
$\mathrm{X}_{1}$ & 0,534 & 0,130 & 0,441 & 0,741 & 1,350 \\
$\mathrm{X}_{2}$ & 0,541 & 0,196 & 0,287 & 0,791 & 1,263 \\
$\mathrm{X}_{3}$ & 0,330 & 0,113 & 0,316 & 0,731 & 1,367 \\
\hline
\end{tabular}

Sumber: Data diolah, 2018

Berdasarkan hasil Uji Multikolinearitas pada Tabel 6 menunjukkan variabel bebas dalam model regresi tidak saling berkorelasi. Diperoleh nilai tolerance dari 
masing-masing variabel lebih dari 0,10 dan nilai VIF diperoleh kurang dari 10. Hal ini menunjukkan tidak adanya korelasi antara sesama variabel bebas dalam model regresi, sehingga dapat disimpulkan bahwa tidak terdapat masalah multikolinearitas.

Hasil uji heterokedastisitas disajikan pada Tabel 7 sebagai berikut.

Tabel 7.

Hasil Uji Heterokedastisitas

\begin{tabular}{|c|c|c|c|c|c|}
\hline \multirow[t]{2}{*}{ Model } & \multicolumn{2}{|c|}{ Unstandardized Coefficients } & \multirow{2}{*}{$\begin{array}{c}\text { Standardized } \\
\text { Coefficients } \\
\text { Beta }\end{array}$} & \multirow[b]{2}{*}{$\mathrm{t}$} & \multirow[b]{2}{*}{ Sig. } \\
\hline & B & Std. Error & & & \\
\hline (Constant) & 4,850 & 1,390 & & 3,489 & 0,001 \\
\hline $\mathrm{X}_{1}$ & $-0,051$ & 0,070 & $-0,134$ & $-0,730$ & 0,470 \\
\hline $\mathrm{X}_{2}$ & $-0,058$ & 0,105 & $-0,098$ & $-0,554$ & 0,583 \\
\hline $\mathrm{X}_{3}$ & $-0,019$ & 0,060 & $-0,058$ & $-0,316$ & 0,754 \\
\hline
\end{tabular}

Sumber:Data diolah, 2018

Berdasarkan Tabel 7 dapat dikatakan bahwa nilai signifikansi masingmasing variabel pada model regresi nilainya lebih dari 0,05 . Hal ini menunjukkan bahwa model regresi tersebut tidak megandung heteroskedastisitas.

Analisis regresi ini digunakan untuk melihat pengaruh variabel $\mathrm{X}$ terhadap variabel Y. Berdasarkan Tabel 8 dapat diringkas model persamaan regresi linear bergandanya sebagai berikut:

$$
Y=-1,749+0,534 X_{1}+0,541 X_{2}+0,330 X_{3}+e
$$

Tabel 8.

Hasil Analisis Regresi Linear Berganda

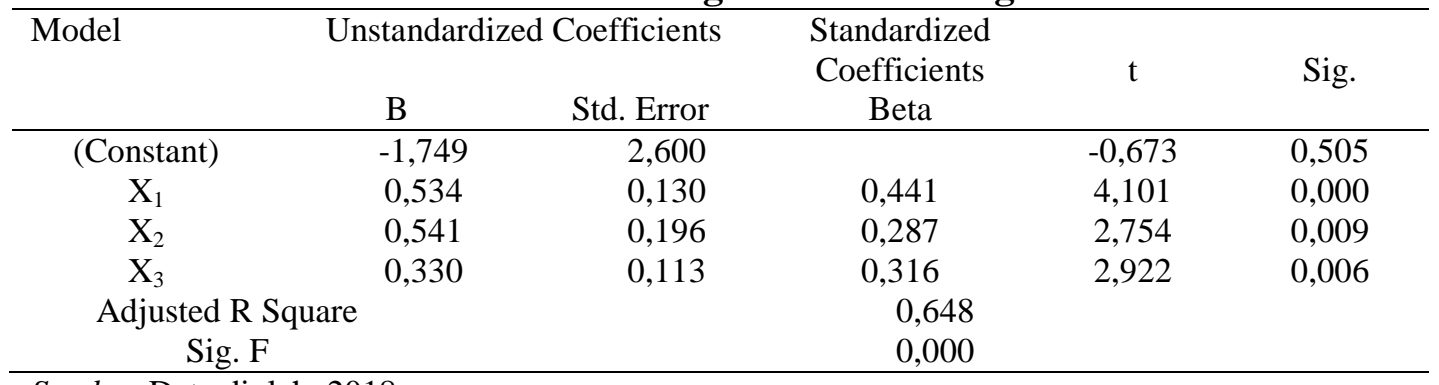

Sumber:Data diolah, 2018 
Komang Sukma Saraswati dan Ida Bagus Dharmadiaksha. Pengaruh ...

Nilai konstanta sebesar -1,749 menunjukkan bahwa variabel budaya organisasi, kedisiplinan, kompetensi sama dengan nol (tetap atau tidak berubah), menyebabkan kinerja pengawasan akan menurun sebesar konstantanya.

Nilai koefisien beta dari variabel budaya organisasi bernilai positif yang berarti bahwa semakin tinggi budaya organisasi, menyebabkan kinerja pengawasan semakin meningkat.

Nilai koefisien beta dari variabel kedisiplinan bernilai positif yang berarti bahwa semakin tinggi kedisiplinan, menyebabkan kinerja pengawasan semakin meningkat.

Nilai koefisien beta dari variabel kompetensi bernilai positif yang berarti bahwa semakin tinggi kompetensi, menyebabkan kinerja pengawasan semakin meningkat.

Variabel budaya organisasi memiliki nilai koefisien beta standardized yang paling tinggi yaitu 0,441, sedangkan variabel kompetensi sebesar 0,316 dan yang paling kecil variabel kedisiplinan sebesar 0,287. Hal tersebut menujukan bahwa variabel budaya organisasi adalah variabel yang berpengaruh dominan terhadap kinerja pengawasan.

Hasil analisis menunjukkan nilai Adjusted Rsquaresebesar 0,648. Ini berarti perubahan yang terjadi pada kinerja pengawasan dapat dijelaskan oleh budaya organisasi, kedisiplinan, dan kompetensi sebesar 64,8 persen, sedangkan sisanya 35,2 persen dijelaskan oleh faktor lain yang tidak diuji dalam penelitian ini.

Berdasarkan Tabel 8, nilai signifikansi $\mathrm{F}$ atau p-value sebesar 0,000 yang kurang dari nilai $\alpha=0,05$. Hal ini menunjukkan bahwa regresi ini layak 
digunakan sebagai alat analisis untuk menguji pengaruh variabel bebas pada variabel terikat.

Berdasarkan Tabel 8 dapat dilihat bahwa nilai koefisien regresi untuk variabel budaya organisasi sebesar 0,534 dengan tingkat signifikansi sebesar $0,000<0,05$, maka $\mathrm{H}_{1}$ diterima. Hal ini mengindikasikan bahwa budaya organisasi berpengaruh positif dan siginifikan terhadap kinerja pengawasan.Adapun budaya organisasi yang diterapkan oleh inspektur daerah Kabupaten Klungkung dan kepala BPKPD Kabupaten Klungkung dapat dilihat dari karakter organisasi dan gaya kepemimpinan yang diterapkan selama menjabat. Keberhasilan budaya organisasi ini dapat dilihat dari jawaban responden yang rata-rata memberikan penilaian positif terhadap pernyataan-pernyataan yang mencerminkan indikator pengukuran dari variabel budaya organisasi, meliputi gaya kepemimpinan dan karakter organisasi. Berdasarkan hasil olahan data kuesioner dapat dibuktikan bahwa budaya organisasi yang baik telah diterapkan oleh inspektur daerah Kabupaten Klungkung dan kepala BPKPD Kabupaten Klungkung, sehingga kinerja pengawasan semakin baik.

Hasil penelitian ini didukung oleh penelitian yang dilakukan Davidson (2013), Limbunan \& Tarigan (2016)juga memberikan hasil bahwa budaya organisasi memberi pengaruh positif terhadap kinerja pengawasan.

Berdasarkan Tabel 8 dapat dilihat bahwa nilai koefisien regresi untuk variabel kedisiplinan sebesar 0,541 dengan tingkat signifikansi adalah $0,009<$ 0,05, maka $\mathrm{H}_{2}$ diterima. Hal ini menunjukkan bahwa kedisiplinan berpengaruh positif pada kinerja pengawasan.Hasil tersebut konsisten dengan jawaban 
Komang Sukma Saraswati dan Ida Bagus Dharmadiaksha. Pengaruh ...

responden, dimana sebagian besar responden memberikan tanggapan positif terhadap setiap pernyataan yang menunjukkan indikator pengukuran kedisiplinan. Hal ini menunjukkan bahwa kedisiplinan telah terapkan oleh inspektur daerah Kabupaten Klungkung dan kepala BPKPD Kabupaten Klungkung kepada pegawai. Kedisiplinan yang diterapkan inspektur daerah Kabupaten Klungkung dan kepala BPKPD Kabupaten Klungkung berupa disiplin waktu yaitu dapat menyelesaikan laporan keuangan tepat waktu, dan disiplin anggaran yaitu dalam penganggaran pengeluaran harus didukung dengan adanya kepastian tersedianya penerimaan dalam jumlah yang cukup.

Herawati et al., (2016) disiplin kerja memiliki pengaruh yang signifikan positif terhadap kinerja pegawai. Hal ini sejalan dengan hasil penelitian yang dilakukan oleh Widari \& Indartono (2015) disiplin berpengaruh positif dan signifikan terhadap kinerja pegawai BKD DIY.

Berdasarkan Tabel 8 dapat dilihat bahwa nilai koefisien regresesi untuk variabel kompetensi sebesar 0,330 dengan tingkat signifikansi adalah 0,006 $<0,05$, maka $\mathrm{H}_{3}$ diterima. Hal ini menunjukkan bahwa kompetensi berpengaruh positif pada kinerja pengawasan.Hubungan positif yang diperoleh dari hasil pengujian mengindikasikan bahwa dengan adanya kompetensi yang dimiliki pegawai maka kinerja pengawasan akan semakin membaik. Hasil tersebut konsisten dengan jawaban responden, dimana sebagian besar responden memberikan tanggapan positif terhadap setiap pernyataan yang menunjukkan indikator pengukuran variabel kompetensi. Ini berarti inspektur daerah Kabupaten Klungkung dan kepala BPKPD Kabupaten Klungkung telah menetapkan kompetensi yang sesuai 
dengan pegawai Inspketorat dan BPKPD Kabupaten Klungkung, sehingga sangat membantu dalam mencapai kinerja pengawasan yang berkualitas. Pemberian pelatihan keterampilan akan membantu menambah wawasan dan keterampilan pegawai, sehingga kemampuan teknis pegawai dalam menjalankan tugas akan semakin membaik. Selain pelatihan keterampilan, latar belakang pengetahuan atau pendidikan seorang pegawai juga tidak kalah pentingnya. Apabila pegawai tidak memiliki pengetahuan yang sesuai dengan pekerjaannya maka akan sulit dalam menyelesaikan tugas.

Ariesta(2013) mengungkapkan bahwa kompetensi sumber daya manusia berpengaruh signifikan terhadap keterandalan dan ketepatwaktuan. Satria (2017) juga memberikan hasil bahwa kompetensi sumber daya manusia berpengaruh signifikan positif terhadap nilai pelaporan keuangan daerah.

Hasil penelitian ini dapat memberikan tambahan informasi dalam kajian empiris mengenai budaya organisasi, kedisiplinan, dan kompetensi terhadap kinerja pengawasan. Terdapat bukti empiris yang diperoleh melalui penelitian ini, menunjukkan bahwa adanya pengaruh positif dari budaya organisasi, kedisiplinan, dan kompetensi terhadap kinerja pengawasan. Hal ini sejalan dengan teori stewardship, para tim audit tidak termotivasi oleh tujuan-tujuan individu tetapi lebih ditujukan pada sasaran hasil utama mereka untuk kepentingan organisasi. Teoristewardship ini didesain bagi para peneliti untuk menguji situasi dimana para eksekutif dalam organisasi sebagai pelayan dapat termotivasi oleh budaya organisasi yang baik, penerapan kedisiplinan, dan penerapan standar kompetensi yang sesuai untuk bertindak dengan cara terbaik pada principal.Hasilpenelitian ini 
dapat memberikan masukkan bagi Inspektur Daerah Kabupaten Klungkung dan Kepala BPKPD Kabupaten Klungkung, sehingga kinerja pengawasan yang baik dan berkualitas dapat tercapai.

\section{SIMPULAN}

Budaya organisasi berpengaruh positif terhadap kinerja pengawasan. Hal ini bermakna bahwa semakin baik budaya organisasi yang dimiliki maka menyebabkan peningkatan terhadap kinerja pengawasan.

Kedisiplinan berpengaruh positif terhadap kinerja pengawasan. Hal ini bermakna bahwa semakin tinggi kedisiplinan pegawai untuk bekerja berdampak terhadap peningkatan kinerja pengawasan.

Kompetensi berpengaruh positif terhadap kinerja pengawasan. Hal ini bermakna bahawa semakin berkompeten pegawai maka kinerja pengawasan akan semakin meningkat.

Inspektur Daerah Kabupaten Klungkung dan Kepala BPKPD Kabupaten Klungkung sebaiknya dapat meningkatkan budaya organisasi. Peningkatan dapat dilakukan pada aspek penerapan sistem akuntansi keuangan sesuai dengan standar akuntansi pemerintahan dan memberi bimbingan kepada bawahannya.

Inspektur Daerah Kabupaten Klungkung dan Kepala BPKPD Kabupaten Klungkung sebaiknya dapat meningkatkan penerapan kedisiplinan. Peningkatan dapat dilakukan pada aspek pelaksanaan disiplin anggaran.

Inspektur Daerah Kabupaten Klungkung dan Kepala BPKPD Kabupaten Klungkung sebaiknya dapat meningkatkan kompetensi yang dimiliki pegawai. 
Peningkatan dapat dilakukan pada aspek sosialisasi atau diklat kepada pegawai apabila ada peraturan baru tentang keuangan daerah.

Hasil penelitian ini agar dapat dijadikan referensi peniliti-peneliti selanjutnya dan dapat mereplikasi penelitian ini dengan menambah variabelvariabel lain yang dapat mempengaruhi kinerja pengawasan seperti motivasi, kompensasi, dan lingkungan kerja.

\section{REFERENSI}

Ali, H. S. H. (2017). The Impact of Organizational Culture On Corporate Financial Performance : A Review. International Journal of Economics, 5(8), 585-597.

Anthony, A. E. (2017). Effects of Discipline Management On Employee Performance in an Organization: The Case of County Education Office Human. International Academic Journal of Human Resource and Business Administration, 2(3), 1-18.

Ariesta, Fadila. (2013). Pengaruh Kualitas Sumberdaya Manusia, Pemanfaatan Teknologi Informasi, dan Pengendalian Intern Akuntansi Terhadap Nilai Informasi Pelaporan Keuangan Pemerintah Daerah. Jurnal Akuntansi, 1(1), $1-17$.

Arifin. (2014). Pengaruh Budaya Organisasi Terhadap Kinerja Perusahaan Daerah Air Minum Kabupaten Bone Bolango. Jurnal Akuntansi, 1(2), 29-42.

Badan Pemeriksa Keuangan Republik Indonesia. 2017. Ikhtisar Hasil Pemeriksaan Semester II Tahun 2017. Diakses pada 12 Juli 2018. Jakarta: http://www.bpk.go.id.

C, O. T., \& Victoria, O. (2011). Effects of Leadership Style on Organizational Performance: A Survey Of Selected Small Scale Enterprises in Ikosi-Ketu Council Development Area Of Lagos State, Nigeria. Journal Of Business And Management, 1(7), 100-111.

Cameron, K. S., \& Quinn, R. E. (2013). Diagnosing And Changing Organizational Culture. Journal Business \& Management, 2(2), 21-43. 
Davidson, G. M. (2013). The Relationship Between Organisational Culture and Financial Performance in a South African Investment Bank. SA Journal Of Industrial Psychology, 33(1), 9-28.

Earnhardt, M. P., \& Bateman, C. (2015). Surveying Organizational Effectiveness: a Case Study From The United Arab Emirates. Journal of Organizational Culture, 19(3), 1-54.

Fleenor, J. W. (2014). Leadership Effectiveness and Organizational Culture : An Exploratory Study. Journal Psychology, 2(1), 1-21. Https://Doi.Org/10.13140/2.1.3756.6406

Golafzani, M. K., \& Chirani, E. (2016). Organizational Culture and The Financial Performance Of Manufacturing Firms. International Journal Of Advanced Biotechnology And Research, 12(2), 1701-1711.

Halim, Abdul. 2013. Analisis Investasi. Edisi 2. Jakarta : Salemba Empat

Handoko, T., Hani. 2003. Manajemen Personalia dan Sumber Daya Manusia. Yogyakarta: BPFE.

Herawati, L. Made, Suputra, D., \& Budiasih. (2016). Pengaruh Pengawasan Pimpinan, Disiplin dan Kompetensi Pegawai Pada Kinerja Pegawai Inspektorat Kabupaten Tabanan. E-Jurnal Ekonomi Dan Bisnis Universitas Udayana, 7(5), 1953-1980.

Hertati, L. (2015). Competence Of Human Resources, The Benefits Of Information Technology On Value Of Financial Reporting In Indonesia. Journal Of Finance And Accounting, 6(8), 12-19.

Hoorn, A. Van. (2017). Organizational Culture in The Financial Sector: Evidence From A Cross-Industry Analysis Of Employee Personal Values And Career. Journal Of Business Ethics, (80044), 1-20. Https://Doi.Org/10.1007/S10551015-2932-6

Iriani, N. I. (2010). Motivasi Intrinsik, Motivasi Ekstrinsik Dan Disiplin Kerja Pengaruhnya Terhadap Kinerja Pegawai Pada Kantor Dinas Pendidikan Kabupaten Sambas. Jurnal Aplikasi Manajemen.

James, M., \& Nyongesa, W. J. (2012). The Impact Of Organisational Culture On Performance Of Educational Institutions. Nternational Journal Of Business And Social Science, 3(8), 211-217.

Lee, W. L., Chong, A. L., \& Ramayah, T. (2018). Organizational Culture And Performance Of Malaysian Manufacturing Firms. International Journal Of Advanced And Applied Sciences, 5(12), 59-66. 
Lillati, S. (2014). Efektivitas Pengawasan Keuangan Daerah Di Kabupaten Tanggamus. Jurnal Akuntansi, 5(1), 21-43.

Limbunan, S., \& Tarigan, J. (2016). Budaya Organisasi Terhadap Kinerja Keuangan Dengan Menggunakan Perilaku Pemilik Atas Isu Manajemen Lingkungan Sebagai Variabel Intervening. Jurnal Kuntansi Bisnis Universitas Kristen Petra, 4(1), 157-168.

Mardiasmo. 2004.Otonomi dan Manajemen Keuangan Daerah. Yogyakarta: Andi.

Moeheriono. 2012. Pengukuran Kinerja Berbasis Kompetensi. Jakarta: Raja Grafindo Persada.

Moenir, H.A.S. 2004. Manajemen Pelayanan Umum Di Indonesia. Jakarta: Bumi Aksara.

Nwinyokpugi, P. (2018). Workplace Discipline; A Catalyst For Organizational Productivity In Nigeria Workplace Discipline: A Catalyst For Organizational Productivity In Nigeria. International Journal Of Innovative Research And Advanced Studies, 5(3), 1-4.

Palan, R. 2007. Competency Management. Jakarta: Penerbit PPM.

Patrick. (2015). Workplace Discipline: A Catalyst For Organizational Productivity In Nigeria. International Journal of Innovative Research and Advanced Studies, 2(3), 24-37.

Peraturan Bupati Nomor 35 Tahun 2016 tentang Kedudukan, Susunan Organisasi, Tugas dan Fungsi Serta Tata Kerja Perangkat Daerah,

Peraturan Menteri Dalam Negeri Nomor 13 Tahun 2006 tentang Pedoman Pengelolaan Keuangan Daerah.

Peraturan Pemerintah Nomor 8 tahun 2006 tentang Pelaporan Keuangan dan Kinerja Instansi Pemerintah.

Peraturan Pemerintah Republik Indonesia Nomor 71 Tahun 2010 Tentang Standar Akuntansi Pemerintahan.

Peraturan Pemerintah Nomor 101 Tahun 2000 tentang Pendidikan dan Pelatihan Jabatan Pegawai Negeri Sipil.

Purwati, Atiek Sri. (2017). Faktor - Faktor yang Mempengaruhi Kualitas Laporan Keuangan Pada Umkm Di Kabupaten Banyumas.Jurnal Ekonomi dan Bisnis, 8(2), 808-818. 
Rahayu, L., Kennedy, \& Anisma, Y. (2014). Pengaruh Kompetensi Sumber Daya Manusia (SDM), Penerapan Sistem Akuntansi Keuangan Daerah, dan Penerapan Standar Akuntansi Pemerintah (SAP) Terhadap Kualitas Laporan Keuangan Daerah Pada Pemerintah Provinsi Riau. Jurnal Ekonomi dan Bisnis, 1(2), 1-15.

Rostarina, R. (2015). Pengaruh Kompetensi Pegawai Terhadap Kinerja Pegawai Pada Balai Pelatihan Kesehatan Dinas Kesehatan Provinsijawa Barat.

Satria, A. (2017). Pengaruh Disiplin Kerja, Kompetensi dan Budaya Organisasi Terhadap Promosi Kualifikasi Perwira Penerbang di Lanud Halim Perdanakusuma Influence. Jurnal Prodi Strategi Pertahanan Udara, 3(1), 125 .

Undang- Undang Republik Indonesia Nomor 17 Tahun 2003 tentang Keuangan Negara.

Undang- Undang Republik Indonesia Nomor 23 Tahun 2014 tentang Pemerintahan Daerah.

Wibowo. 2007. Manajemen Kinerja. PT. Raja Grafindo Parsada: Jakarta.

Widari, T., \& Indartono, S. (2015). Pengaruh Disiplin dan Lingkungan Kerja Terhadap Kinerja Pegawai. Jurnal Manajemen, 4(1), 305-316.

Yesil, S., \& Kaya, A. (2013). The Effect Of Organizational Culture On Firm Financial Performance: Evidence From A Developing Country. International Academic Journal of Business, 81(3), 428-437. Https://Doi.Org/10.1016/J.Sbspro.2013.06.455

Yosefrinaldi. (2017). Pengaruh Kapasitas Sumber Daya Manusia dan Pemanfaatan Teknologi Informasi Terhadap Kualitas Laporan Keuangan Pemerintah Daerah Dengan Variabel Intervening Sistem Pengendalian Intern Pemerintah. Jurnal Ekonomi Dan Bisnis, 5(3), 1-24. 